\title{
FAKTOR YANG BERHUBUNGAN DENGAN KADAR CHOLINESTERASE DARAH PEKERJA BAGIAN PENYEMPROTAN PT. ANGLO EASTERN PLANTIONS
}

\author{
Dian Maya Sari Siregar ${ }^{*}$, Mutiara Saragih² \\ ${ }^{1,2}$ Program Studi S1 Kesehatan Masyarakat, Fakultas Kesehatan Masyarakat, Institut \\ Kesehatan Helvetia, Jalan Kapten Sumarsono No. 107, Medan 20124, Indonesia
}

*Penulis Korespondensi: Dian Maya Sari Siregar, Program Studi S1 Kesehatan Masyarakat, Fakultas Kesehatan Masyarakat, Institut Kesehatan Helvetia, Jalan Kapten Sumarsono No. 107, Medan 20124, Indonesia, e-mail: dianmayasari.srg@gmail.com, Phone: 081370875010

\begin{abstract}
The spraying process is a condition where workers are very likely to be exposed to toxic chemicals contained in pesticides. Problems encountered in the field, workers do not spray with the correct method and do not use a complete PPE. The danger that can occur when spraying is a disturbance in the enzyme Cholinesterase (CHE) in the blood. CHE is an enzyme that is in the body's tissues has a role to keep nerve cells, muscles and glands working properly. The purpose of this study was to determine the factors related to CHE levels in spraying workers. The research design used analytical research with cross sectional approach. The population was 30 spraying workers. The sampling technique used a total population of 30 people. Data analysis used univariate and bivariate analysis tested by Fisher Exact Test statistical test. Data obtained by questionnaire and examination of CHE levels through blood samples. The results with bivariate analysis revealed p-value of each variable, namely age 0.143>0.05, gender 1,000>0.05, education level 0.374>0.05, years of service 0.071 >0.05, duration of exposure 0.02<0.05, spraying method 0,000<0.05, the last spraying time was $0.210>0.05$ and PPE $0.001<0.05$. The conclusion shows that there is a relationship between the length of exposure to pesticides, how to spray and PPE with CHE levels.
\end{abstract}

\section{Keywords: Related Factors, Cholinesterase Levels, Spraying Workers}

\section{PENDAHULUAN}

Sektor pertanian menjadi sektor penting dalam pembangunan ekonomi nasional. Peran sektor pertanian digambarkan melalui kontribusinya dalam penyedia bahan pangan (1). WHO mencatat pada tahun 2011, dari 160 negara ada 570 juta penduduk bermata pencaharian sebagai petani (2). Pada tahun 2018, BPS melaporkan jumlah pekerja petani Provinsi Sumatera Utara adalah 1.267.206 orang dari 14.415.391 total penduduk atau sekitar 8,8\% (3).

Peranan pestisida dalam penyelamatan produksi pertanian dari gangguan hama dan penyakit tanaman sangat besar (4). Menurunnya kadar CHE darah dapat disebabkan oleh akumulasi bahan pestisida yang masuk ke dalam tubuh melalui kontaminasi kulit, melalui 
sistem respirasi maupun melalui sistem pencernaan (5). Seseorang yang mengalami keracunan pestisida akan memiliki kadar $C H E$ yang rendah (6).

WHO tahun 2014 memperkirakan setiap tahun terdapat 1-5 juta kasus keracunan pestisida pekerja pertanian dengan jumlah kematian mencapai 20.000 jiwa. Sekitar 80\% keracunan dilaporkan terjadi di negara-negara berkembang (2). Angka keracunan pestisida beberapa daerah di Indonesia sangat tinggi. Menurut Kemenkes RI (2014), CHE darah terhadap 347 pekerja pada bidang pertanian ditemukan 23,64\% pekerja keracunan sedang dan $35,73 \%$ keracunan berat. Seseorang yang keracunan pestisida akan memiliki kadar CHE yang rendah. Gejala dan tanda keracunan bervariasi meliputi sakit kepala, kelemahan atau keletihan menyeluruh, berkeringat, muntah, pandangan kabur dan kejang (7).

Menurut Achmadi, faktor yang memengaruhi kadar $C H E$, antara lain faktor internal yang terdiri dari usia, jenis kelamin, tingkat pendidikan dan faktor eksternal terdiri dari lama penyemprotan, tindakan penyemprotan terhadap arah mata angin, waktu terakhir penyemprotan dan penggunaan APD (8). Penelitian Aulia (2017), menunjukkan faktor lama bekerja berpengaruh kuat terhadap penurunan kadar $C H E$ darah dan menyatakan bahwa terdapat hubungan antara tingkat pengetahuan petani, masa kerja petani, dan lama kerja petani (9).

PT. Anglo Eastern Plantations merupakan perusahaan perkebunan kelapa sawit multinasional yang mengembangkan empat perkebunan di Sumatera Utara. Menurut hasil survey terdahulu, pada tahun 2017 dari pekerja bagian penyemprotan yang berjumlah 55 orang ada 10 karyawan mengalami peningkatan kadar CHE. Tahun 2018 dari 40 jumlah pekerja bagian penyemprotan sebanyak 9 pekerja mengalami peningkatan kadar $C H E$, dan belum diketahui dengan pasti faktor yang menyebabkan peningkatan kadar $C H E$ pada karyawan setiap tahun.

Hasil survei awal menunjukkan beberapa pekerja tidak melakukan penyemprotan dengan benar dan aman. Keluhan yang sering dialami pekerja bagian penyemprotan seperti pusing sampai mual. Penelitian ini bertujuan mengetahui faktor yang berhubungan dengan kadar $C H E$ dalam darah pekerja bagian penyemprotan PT. Anglo Eastern Plantations.

\section{METODE}

Penelitian menggunakan pendekatan cross sectinal. Penelitian dilakukan di PT. United Kingdom Plantations, dilakukan pada bulan Maret-Juli 2019. Populasi penelitian adalah seluruh pekerja penyemprotan di PT. Anglo Eastern Plantation yang berjumlah 30 orang dan keseluruhannya dijadikan sampel. Penelitian menggunakan analisis univariat dan bivariat 
dengan uji Fisher Exact Test kemudian data disajikan dalam bentuk tabel distribusi frekuensi dan tabulasi silang.

\section{HASIL}

Tabel.1. Distribusi Frekuensi Usia, Jenis Kelamin, Tingkat Pendidikan, Masa Kerja, Lamanya Terpapar, Cara Penyemprotan, Waktu Terakhir Penyemprotan dan Alat Pelindung Diri Responden di PT. Anglo Eastern Plantations

\begin{tabular}{|c|c|c|}
\hline Variabel & Frekuensi (f) & Persentase (\%) \\
\hline \multicolumn{3}{|l|}{ Usia } \\
\hline$\leq 18$ Tahun & 5 & 16,7 \\
\hline$>18$ Tahun & 25 & 83,3 \\
\hline \multicolumn{3}{|l|}{ Jenis Kelamin } \\
\hline Laki-laki & 5 & 16,7 \\
\hline Perempuan & 25 & 83,3 \\
\hline \multicolumn{3}{|l|}{ Tingkat Pendidikan } \\
\hline Rendah & 22 & 73,3 \\
\hline Menengah & 8 & 26,7 \\
\hline \multicolumn{3}{|l|}{ Masa Kerja } \\
\hline$\leq 5$ Tahun & 7 & 23,3 \\
\hline$>5$ Tahun & 23 & 76,7 \\
\hline \multicolumn{3}{|l|}{ Lamanya Terpapar Pestisida } \\
\hline$\leq 5 \mathrm{Jam}$ & 17 & 56,7 \\
\hline$>5 \mathrm{Jam}$ & 13 & 43,3 \\
\hline \multicolumn{3}{|l|}{ Cara Penyemprotan Searah Mata Angin } \\
\hline Searah dengan mata angin & 23 & 76,7 \\
\hline Berlawanan dengan mata angin & 7 & 23,3 \\
\hline \multicolumn{3}{|l|}{ Waktu Terakhir penyemprotan } \\
\hline$>2$ Minggu & 9 & 30,0 \\
\hline$\leq 2$ Minggu & 21 & 70,0 \\
\hline \multicolumn{3}{|l|}{ Alat Pelindung Diri (APD) } \\
\hline Menggunakan APD lengkap & 23 & 76,7 \\
\hline Tidak menggunakan APD lengkap & 7 & 23,3 \\
\hline \multicolumn{3}{|l|}{ Kadar Cholinesterase } \\
\hline Normal & 21 & 70,0 \\
\hline Tidak Normal & 9 & 30,0 \\
\hline
\end{tabular}

Eastern Plantations paling banyak berusia < 18 tahun, berjenis kelamin perempuan, berpendidikan rendah, masa kerja $>5$ tahun, lamanya terpapar pestisida dalam satu hari $\leq 5$ jam, cara penyemprotan searah dengan mata angin, waktu terakhir penyemprotan $\leq 2$ minggu, menggunakan APD lengkap, dan hasil pemeriksaan darah test cholinesterase kategori normal.

Tabel 2 Hubungan Usia, Jenis Kelamin, Tingkat Pendidikan, Masa Kerja, Lamanya Terpapar, Cara Penyemprotan, Waktu Terakhir Penyemprotan dan Alat Pelindung Diri dengan Kadar Cholinesterase pada Pekerja Penyemprotan PT. Anglo Eastern Plantations

\begin{tabular}{|c|c|c|c|c|c|c|c|}
\hline \multirow[t]{2}{*}{ Variabel } & \multicolumn{2}{|c|}{ Normal } & \multicolumn{2}{|c|}{$\begin{array}{c}\text { Tidak } \\
\text { Normal }\end{array}$} & \multicolumn{2}{|c|}{ Total } & \multirow[t]{2}{*}{ p-value } \\
\hline & $\mathbf{f}$ & $\%$ & $\mathbf{f}$ & $\%$ & f & $\%$ & \\
\hline \multicolumn{8}{|l|}{ Usia } \\
\hline$\leq 18$ Tahun & 2 & 6,7 & 3 & 10,0 & 5 & 16,7 & 0,143 \\
\hline$>18$ Tahun & 19 & 63,3 & 6 & 20,0 & 25 & 83,3 & \\
\hline \multicolumn{8}{|l|}{ Jenis Kelamin } \\
\hline Laki-laki & 4 & 13,3 & 1 & 3,3 & 5 & 16,7 & \\
\hline Perempuan & 17 & 56,7 & 8 & 26,6 & 25 & 83,3 & 1,000 \\
\hline
\end{tabular}




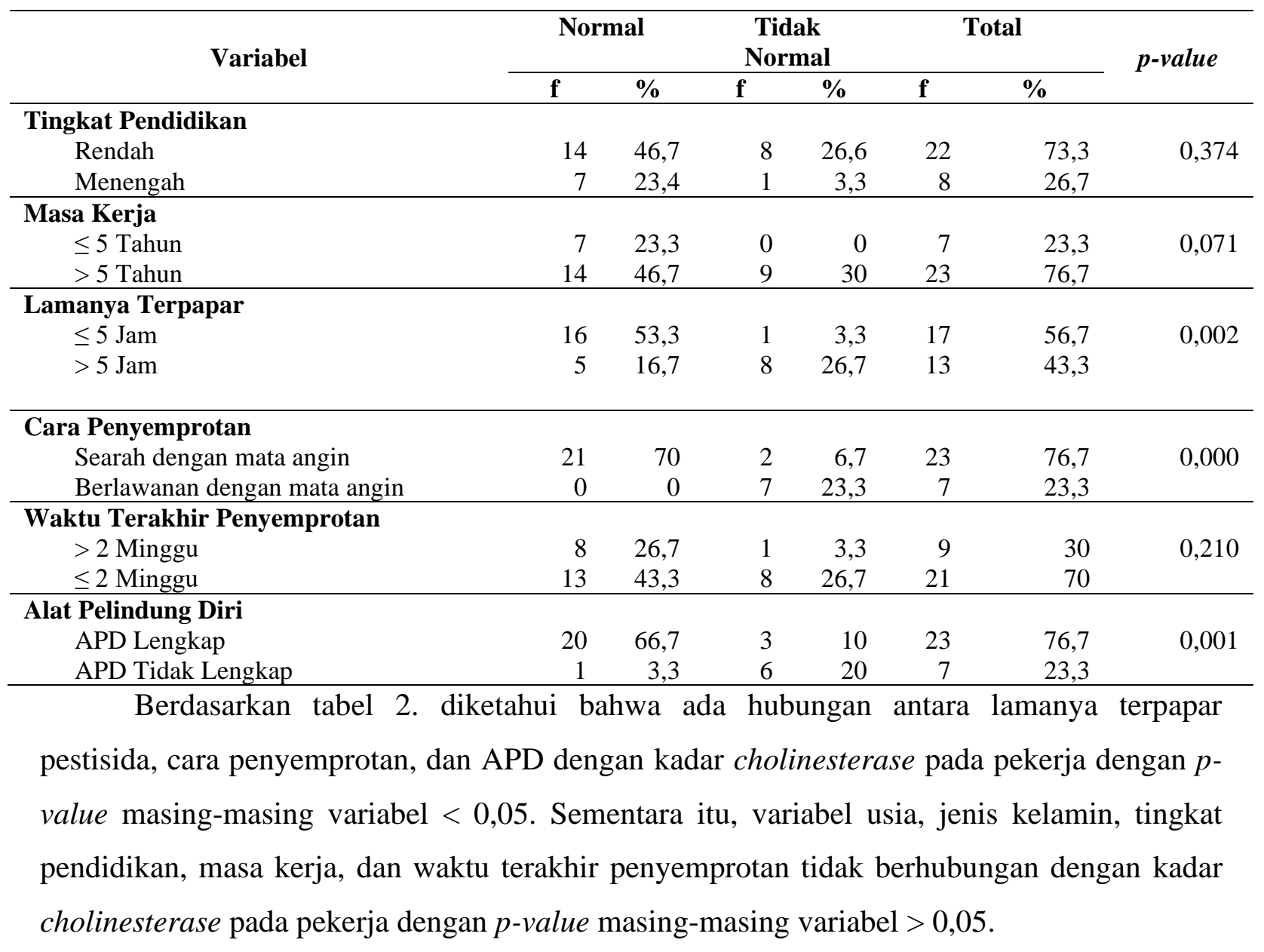

\section{PEMBAHASAN}

\section{Hubungan Usia dengan Kadar Cholinesterase pada Pekerja Penyemprotan PT. Anglo Eastern Plantations}

Hasil penelitian menunjukkan tidak ada hubungan usia dengan kadar cholinesterase pekerja dengan $p$-value $=0,143$. Tidak sejalan dengan penelitian yang dilakukan Trya (2017) yang menyatakan ada hubungan usia dengan kadar cholinesterase dengan $p$-value $=0,007$ (10). Tidak sejalan pula dengan penelitian Fitrisyah (2018) yang menyatakan tidak ada hubungan usia dengan kadar cholinesterase dengan $p$-value $=0,001$ (11).

Semakin bertambah umur seseorang semakin banyak pemaparan yang dialami bila pekerja selalu terpapar oleh pestisida. Semakin tua seseorang, efektifitas sistem kekebalan di dalam tubuh semakin berkurang (6). Sesuai dengan Permenaker RI No. PER-03/MEN/1986, tenaga yang mengelola pestisida harus berumur 18 tahun ke atas karena pekerjaan tersebut dapat membahayakan kesehatan bila bekerja tidak sesuai prosedur (12).

Menurut peneliti, usia adalah salah satu faktor yang mempengaruhi kondisi kesehatan tubuh seseorang. Pada penelitian ini, usia tidak berpengaruh dengan kadar cholinesterase karena paparan pestisida akan menimbulkan dampak yang sama ketika terserap oleh tubuh 
yaitu meningkatnya kadar cholinesterase dalam darah.

\section{Hubungan Jenis Kelamin dengan Kadar Cholinesterase pada Pekerja Penyemprotan PT. Anglo Eastern Plantations}

Hasil penelitian menunjukkan tidak ada hubungan jenis kelamin dengan kadar cholinesterase pekerja dengan $p$-value $=1,000$. Sejalan dengan penelitian Mahyuni (2014) menyatakan tidak ada hubungan jenis kelamin dengan kadar cholinesterase dengan $p$-value $=$ 0,380 (13). Namun sejalan dengan penelitian Puspitasari (2016) menyatakan ada hubungan jenis kelamin dengan kadar cholinesterase dengan $p$-value $=0,000$ (14).

Menurut Frank, jenis pekerjaan yang dilakukan saat melakukan penyemprotan hakikatnya sama. Kadar cholinesterase terganggu apabila seorang wanita dalam kondisi hamil, hormon yang terkandung di dalam tubuhnya akan mempengaruhi jumlah kadar cholinesterase dalam darah juga dapat menyebabkan kelahiran prematur dan BBLR (6).

Menurut peneliti, tidak ada hubungan jenis kelamin dengan penurunan enzim cholinesterase karena dalam bekerja dengan pestisida, pekerjaan antara laki-laki dan perempuan tidak berbeda. Di lapangan yang terlihat, perempuan memiliki tugas sama dengan laki-laki saat penyemprotan. Sehingga mereka dapat mengalami gangguan enzim cholinesterase dikarenakan memiliki kontak yang dekat dengan pestisida. Pekerja laki-laki maupun perempuan ada beberapa yang tidak menggunakan masker. Pengaplikasian pestisida dengan cara disemprotkan memungkinkan butiran cairan melayang, menyimpang dari aplikasi. Jarak yang ditempuh oleh butiranan cairan tergantung pada ukuran butiran. Butiran dengan radius $<1$ micron dianggap sebagai gas yang kecepatan mengendapnya tak terhingga, sedangkan butiran dengan radius lebih besar akan lebih cepat mengendap.

\section{Hubungan Tingkat Pendidikan dengan Kadar Cholinesterase pada Pekerja Penyemprotan PT. Anglo Eastern Plantation}

Hasil penelitian menunjukkan tidak ada hubungan tingkat pendidikan dengan kadar cholinesterase pekerja dengan $p$-value $=0,374$. Sejalan dengan penelitian Mahyuni (2014) yang menyatakan ada hubungan pendidikan dengan kadar cholinesterase dengan $p$-value $=$ $0,002(13)$.

Tingkat pendidikan lebih tinggi memudahkan masyarakat menyerap informasi serta mengimplementasikan dalam perilaku dan gaya hidup. Pekerja berpendidikan tinggi maupun rendah wajib menggunakan pestisida sesuai aturan. Petani yang tingkat pendidikannya lebih tinggi sebaiknya memberikan ilmu yang dimiliki kepada petani yang pendidikannya lebih rendah guna meningkatkan pengetahuan pada petani. Pendidikan adalah upaya persuasi atau pembelajaran pada masyarakat agar mau melakukan tindakan (praktik) untuk memelihara 
(mengatasi masalah) dalam kehidupan. Pendidikan formal maupun informal yang diperoleh seseorang akan memberikan tambahan pengetahuan. Dengan pendidikan yang tinggi diharapkan pengetahuan penggunaan pestisida dan cara mengatasi jika terjadi keracunan pestisida akan lebih baik dibanding dengan pendidikan rendah (8).

Menurut peneliti, pekerja yang berada di PT. Anglo Eastern Plantations mayoritas memiliki tingka pendidikan rendah. Saat penelitian dilakukan diketahui bahwa perusahaan sudah memberikan panduan tentang pestisida dalam Bahasa Indonesia yang sangat mudah dimengerti pekerja, sehingga tidak sulit dalam memahami prosedur penggunaan pestisida. Pekerja juga diberi penyuluhan kesehatan pola hidup sehat per satu semester untuk meningkatkan pengetahuannya.

\section{Hubungan Masa Kerja dengan Kadar Cholinesterase pada Pekerja Penyemprotan PT. Anglo Eastern Plantations}

Hasil penelitian menunjukkan tidak ada hubungan masa kerja dengan kadar cholinesterase pekerja dengan $p$-value $=0,071$. Sejalan dengan penelitian Mahyuni (2014) bahwa tidak ada hubungan masa kerja dengan kadar cholinesterase petani yang bekerja di bagian penyemprotan dengan $p$-value $=0,083$ (13).

Semakin lama penyemprot kontak dengan pestisida, akan semakin tinggi risiko terjadi keracunan pestisida apabila pekerja tidak melakukan penyemprotan dengan prosedur yang tepat. Penyemprot pestisida sebelum menggunakan pestisida harus mengikuti petunjuk pada label, apabila terjadi luka maka tutup dengan perban agar pestisida tidak terserap(5).

Menurut peneliti, pekerja bagian penyemprot yang sudah bekerja $\geq 5$ tahun dianggap sudah berpengalaman melakukan pekerjaannya. Perusahaan rutin memberi pelatihan terkait aturan memakai APD dan penyuluhan aturan pemakaian pestisida agar dapat bekerja dengan aman dan nyaman. Pekerja juga tidak terus menerus melakukan kegiatan penyemprotan. Ada waktu dimana petani tidak melakukan kegiatan tersebut. Lama waktu yang diperlukan agar kadar kolinesterase kembali normal tergantung pada tipe dan tingkat keracunan. Selain itu, kadar cholinesterase darah dapat kembali normal jika memperhatikan status gizi yang baik.

\section{Hubungan Lamanya Terpapar dengan Kadar Cholinesterase pada Pekerja Penyemprotan PT. Anglo Eastern Plantations}

Hasil penelitian menunjukkan ada hubungan lama terpapar dengan kadar cholinesterase pekerja dengan $p$-value $=0,002$. Sejalan dengan penelitian Rusma (2016) yang menyatakan ada hubungan lamanya terpapar pestisida dengan kadar cholinesterase darah dengan $p$-value $=0,004(15)$.

Pekerja tidak boleh bekerja > 5 jam dalam satu hari kerja, bila aplikasi pestisida oleh 
pekerja berlangsung dari hari ke hari secara kontinyu dan berulang dalam waktu lama. Semakin lama seorang petani terpapar pestisida maka semakin banyak pestisida yang terabsorbsi dalam tubuhnya. Melakukan penyemprotan sebaiknya tidak boleh lebih dari 5 jam, bila melebihi maka risiko keracunan semakin besar. Seandainya masih harus menyelesaikan pekerjaan, hendaklah istirahat terlebih dulu beberapa saat guna memberikan kesempatan tubuh terbebas dari paparan pestisida (16).

Menurut peneliti, pekerja yang melakukan penyemprotan > 5 jam per hari akan mengalami kelelahan dan sistem imunitas menurun, sehingga pestisida mudah masuk ke dalam tubuh. Menurut data yang diperoleh, pekerja banyak melakukan penyemprotan $>5$ jam dengan alasan jika pekerja lembur maka akan mendapatkan penghasilan tambahan.

\section{Hubungan Cara Penyemprotan dengan Kadar Cholinesterase pada Pekerja}

\section{Penyemprotan PT. Anglo Eastern Plantations}

Hasil penelitian menunjukkan ada hubungan cara penyemprotan dengan kadar cholinesterase pekerja dengan $p$-value $=0,000$. Sejalan dengan penelitian Suparti (2016) yang menyatakan ada hubungan cara penyemprotan dengan kadar cholinesterase dengan $p$ value $=0,003$ (17). Sejalan juga dengan penelitian Yeviana bahwa ada hubungan cara penyemprotan dengan kadar cholinesterase dengan $p$-value $=0,001$ (18).

Kebiasaan menyemprot melawan arah mata angin merupakan salah satu faktor penyebab kadar cholinesterase abnormal. Cara penyemprotan pestisida ada 2 jenis, yaitu searah dan tidak searah arah angin. Arah mata angin harus diperhatikan saat menyemprot agar pestisida yang disemprotkan tidak berbalik kepada penyemprot karena arah mata angin yang berlawanan. Bila penyemprotan tidak searah dengan arah angin, maka pestisida dapat mengenai tubuh atau terhirup sehingga menyebabkan keracunan (8).

Menurut peneliti, bila pekerja melakukan penyemprotan tidak searah mata angin maka angin akan mengarahkan pestisida kepada penyemprot dan dapat mengenai tubuh pekerja. Kejadian di lapangan adalah beberapa pekerja terkadang melepaskan maskernya saat selesai melakukan penyemprotan namun masih di dalam lingkungan kerja, tanpa disadari pestisida yang disemprotkan belum seluruhnya jatuh tetapi masih banyak yang tersebar di udara yang arah mata anginnya mengarah kepada pekerja.

\section{Hubungan Waktu Terakhir Penyemprotan dengan Kadar Cholinesterase pada Pekerja Penyemprotan PT. Anglo Eastern Plantations}

Hasil penelitian menunjukkan tidak ada hubungan waktu terakhir penyemprotan dengan kadar cholinesterase pekerja dengan $p$-value $=0,210$. Hal ini sejalan dengan penelitian Yeviana bahwa tidak ada hubungan waktu terakhir penyemprotan dengan kadar 
cholinesterase dengan $p$-value $=0,340>0,05(18)$.

Aktivitas asetil cholinesterase berkurang karena adanya pestisida dalam darah yang membentuk senyawa phosphorilated cholinesterase, sehingga enzim tersebut tidak dapat berfungsi lagi. Akibatnya kadar yang aktif dari enzim asetilcholinesterase akan berkurang. Oleh karena itu pengukuran enzim tersebut di dalam darah dapat digunakan untuk mendiagnosa kemungkinan dan tidak dipengaruhi oleh waktu terakhir pekerja terpapar pestisida. Pestisida dalam tubuh tidak akan bertahan lama karena akan diproses oleh tubuh apabila tidak di serap ke dalam darah. Pekerja yang kontak dengan pestisida hanya tiap seminggu atau sebulan sekali dapat terhindar dari penurunan aktivitas cholinesterase darah karena adanya rentang istirahat yang cukup untuk menormalkan kembali cholinesterase darahnya (5).

Menurut peneliti waktu terakhir penyemprotan tidak berhubungan dengan kadar cholinesterase karena pengambilan darah dilakukan di atas 24 jam dimana kadar cholinesterase dalam tubuh sudah terproses dengan baik oleh tubuh sehinngga jumlahnya akan kembali normal di dalam darah.

\section{Hubungan Alat Pelindung Diri dengan Kadar Cholinesterase pada Pekerja Penyemprotan PT. Anglo Eastern Plantation}

Hasil penelitian menunjukkan ada hubungan APD dengan kadar cholinesterase pekerja dengan $p$-value $=0,001$. Sejalan dengan penelitian Entianopa (2017) bahwa ada hubungan penggunaan APD dengan kadar cholinesterase pekerja dengan $p$-value $=0,004$ (4).

Berdasarkan Peraturan Menteri Tenaga Kerja dan Transmigrasi RI No PER.08/MEN/VII/2010 tentang Alat Pelindung Diri meliputi alat pelindung kepala, mata, telinga, pernapasan, tangan dan kaki. Penggunaan APD oleh penyemprot pestisida akan menurunkan risiko terpajan pestisida. Berdasarkan Permenkes No. 258/ MENKES/PER/III/1992 tentang Persyaratan Penggunaan Pestisida, untuk perlengkapan pelindung minimal harus berdasarkan jenis pekerjaan dan klasifikasi pestisida (19).

Menurut peneliti, penggunaan APD oleh penyemprot pestisida akan menurunkan risiko terpanjan pestisida. Penggunaan APD yang tidak lengkap dapat menyebabkan pestisida lebih mudah masuk ke dalam tubuh misal seperti menyerap melalui kulit bahkan terhirup melalui saluran pernafasan karena bagian tidak dilindungi oleh APD. Di lapangan ditemukan beberapa pekerja merasa risih menggunakan APD karea dapat mengganggu proses kerja.

\section{KESIMPULAN}


Berdasarkan penelitian dapat disimpulkan bahwa ada hubungan antara lamanya terpapar pestisida, cara penyemprotan dan penggunaan APD dengan kadar cholinesterase dalam darah pekerja bagian penyemprotan PT. Anglo Eastern Plantations.

\section{KATA PENGANTAR}

Peneliti mengucapkan terimakasih kepada pimpinan dan karyawan PT. Anglo Eastern Plantations serta seluruh responden yang banyak memberikan bantuan dan dukungan dalam menyelesaikan penelitian ini.

\section{REFERENSI}

1. Kementerian Pertanian. Renstra Kementerian Pertanian. Jakarta; 2015.

2. Singh. Background paper for The State of Food and Agriculture. 2014.

3. Badan Pusat Statistik / BPS-Statistics Indonesia. Hasil Survei Pertanian Antar Sensus (SUTAS) 2018. 2018.

4. Entiamopa. Paparan Pestisida Pekerja Chemis. 2017;

5. Djojosumarto P. Pestisida \& Aplikasinya. Cikampek; 2016.

6. Frank. Toksikologi Dasar. Edi, editor. Jakarta: Universitas Indonesia; 2010.

7. Sentra Informasi Keracunan Nasional (SIKerNas). Sentra Informasi Keracunan Nasional Berita Keracunan Bulan Juli -September 2017. 2017.

8. Achmadi. Kesehatan Masyarakat Teori dan Aplikasi. Jakarta: Raja Grafindo Persada; 2013.

9. Aulia D. Lama Bertani dan Hubungannya dengan Cholinesterase Darah Petani. 2017;

10. Trya N. Faktor-Faktor yang Berhubungan dengan Kejadian Keracunan Pestisida. $2017 ;(6)$.

11. Fitrisya. Hubungan Masa Kerja, Lama Kerja, Lama Penyemprotan dan Frekuensi Penyemprotan terhadap Kadar Kolinesterase dalam Darah pada Petani. 2018;

12. Menteri Tenaga Kerja RI. Peraturan Menteri Tenaga Kerja Republik Indonesia No: PER-03 /MEN/1986. 1986.

13. Mahyuni E. Faktor Risiko Dalam Penggunaan Pestisida terhadap Keluhan Kesehatan Pada Petani. Kesmas. 2014;9(1):79-89.

14. Puspitarani D. Gambaran Perilaku Penggunaan Pestisida dan Gejala Keracunan yang ditimbulkan pada Petani Penyemprot. 2016;3(1):56.

15. Rusma N. Analisis Kandungan Kadar Cholinesterase Darah pada Petani Penyemprot Pestisida. Jurnal IKMAS. 2016.

16. Buntarto. Panduan Praktis Keselamatan \& Kesehatan Kerja. Yogyakarta: Pustaka Baru Press; 2015.

17. Suparti $S$ dkk. Beberapa faktor risiko yang berpengaruh terhadap kejadian keracunan pestisida pada petani. J Pena Med. 2016;6(2):125-38.

18. Yeviana. Pengaruh Faktor Karakteristik Petani dan Metode Penyemprotan terhadap Kadar Kolinesterase. :85-94.

19. Depnakertrans. PER 08 MEN VII 2010 Tentang Alat Pelindung Diri. Peraturan Menteri. 2010. 1-69 p. 